D倾问がある。5) 珪酸：1，2月は㻆人，5，6月に娍

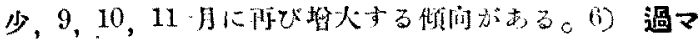
ンガン酸カリウム消量量 $1 ， 2 ３$ 月は減少，5，6月级

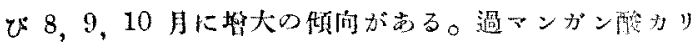

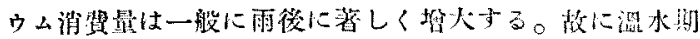

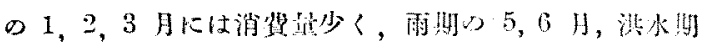

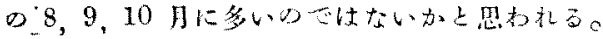

むすび 以上碓行なる原四は推誃し得ないが，6河川!

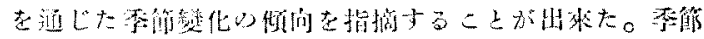

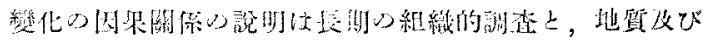

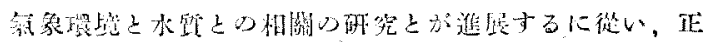

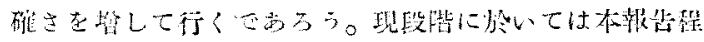

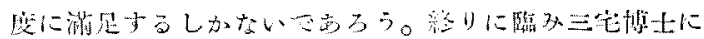

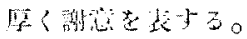

\title{
膠質溶液の滲透壓に關する研究（第5 報）
}

\section{ボリ醋酸ヴィニルーメタノール柔に於ける分子量による沴透壓的擧動の變化}

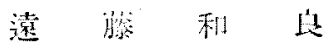

\section{I. 緒}

$\overline{\overline{⿳ 亠 二 口}}$

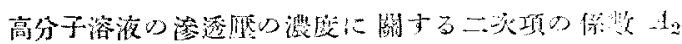

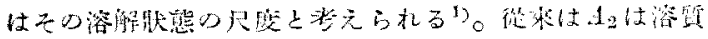

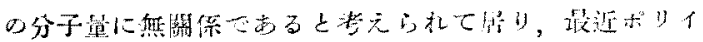

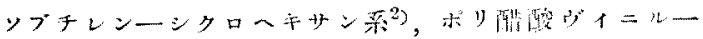

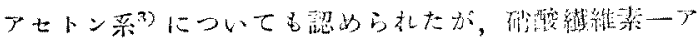

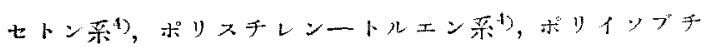

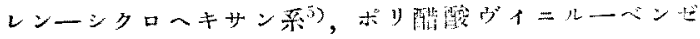

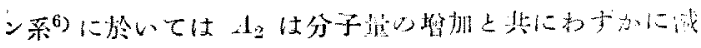

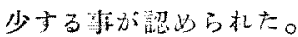

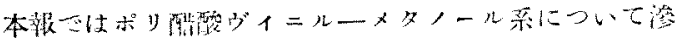

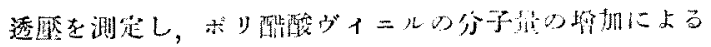

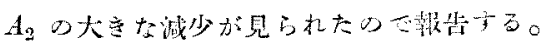

\section{2. 透紗測定結果}

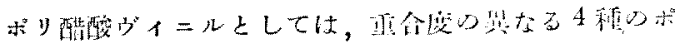

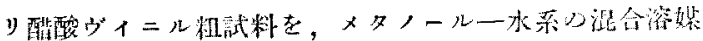
を用いてコアせルローションを利肌して分制を行い，民

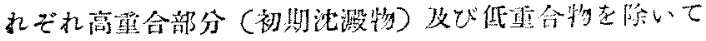
得た，比楥的均一な4 種の試料を目いた。

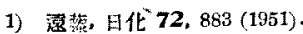

2) M.J. Huggias, 7nd. Eng. Chem. 35, 210, 980 (194).

3) R. E, Robertson, R. Mo. Intosh, W. E. Grumitt, Can. J. Resaarch 24, 150 (1946).

4) G. V. Schalz. Z. physik Chem. A 176, 317 (1936).

5) P. J. Flory, J. Am. Chem. Soc. 65, 372 (1943).

6) C. R. Masson, H. W. Melville, J. Polymer Sci. 4, 337 $(1949)$.

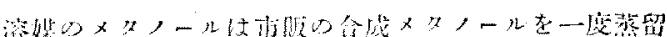

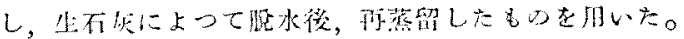

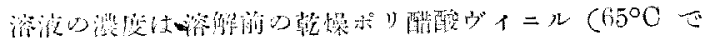

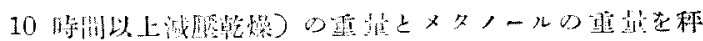

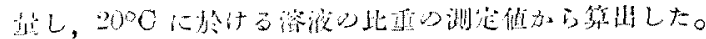

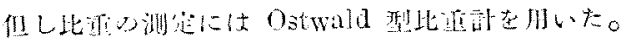

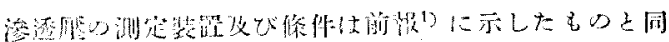

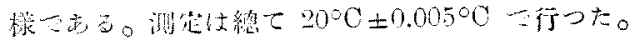

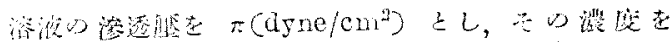

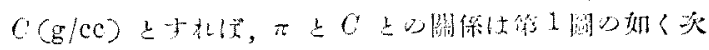

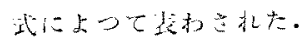

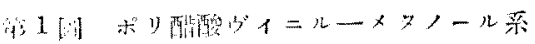

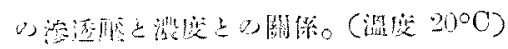

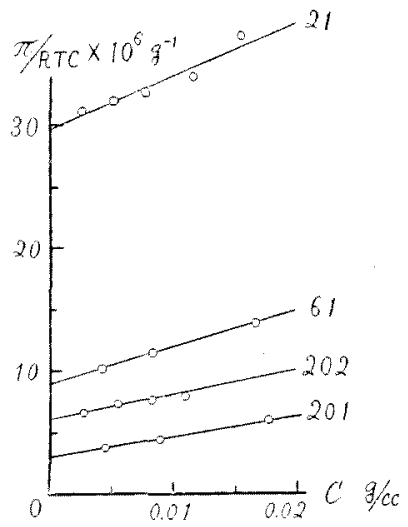

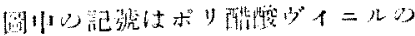
裡颣示示。 


$$
\pi / R T C=A_{1}+A_{2} C
$$

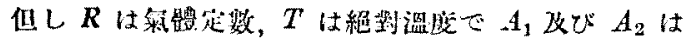
溊度によらない定数でする。

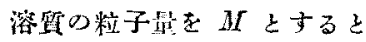

$$
M I=1 / A_{1}
$$

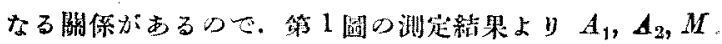

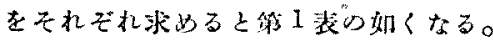

籍口表 P.V.Ac. $-\mathrm{MeOH}$ 系の $A_{1}$ 改び $A_{3}$

(㩜度 $20^{\circ} \mathrm{C}$ )

\begin{tabular}{c|c|c|c} 
塎 枈 & $A_{1} \times 10^{6} \mathrm{~g}^{-1}$ & $M \times 10^{-4} \mathrm{~g}$ & $A_{2} \times 10 \mathrm{~cm}^{3} \mathrm{~g}^{-2}$ \\
\hline P.V.Ac. 21 & 29.8 & 3.36 & 440 \\
P.V.Ac. 61 & 9.1 & 11.0 & 288 \\
P.V.Ac. 202 & 6.3 & 16.1 & 180 \\
P.V.Ac. 201 & 3.04 & 33.0 & 170 \\
\hline
\end{tabular}

但し， $A_{1}, M, A_{2}$ は其心土5\%の䛤差在持つ之溇元

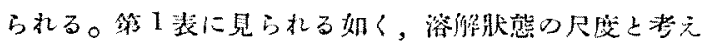

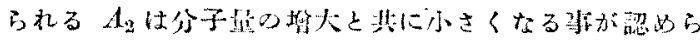

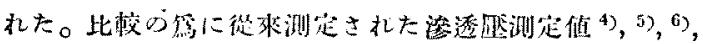

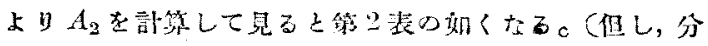
子量に上り $A_{2}$ が變化するものの办を揭げた。

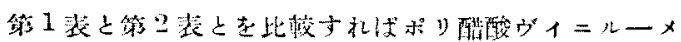

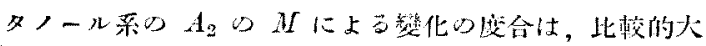
导い斿知的る。

\begin{tabular}{|c|c|c|}
\hline , 溶液 采 & $M \times 10^{-1}$ の變 & $1_{2} \times 10^{6} \sigma$ 戀化 \\
\hline 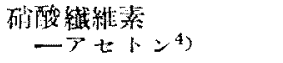 & $5 \sim 44.3$ & $1350-832$ \\
\hline 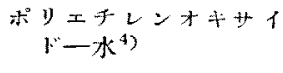 & $23.1 \sim 88.5$ & $3370 \sim 2080$ \\
\hline 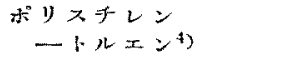 & $6.8 \sim 4^{\circ} .2$ & $87 t \sim 437$ \\
\hline 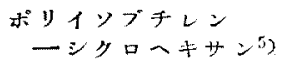 & $2.9 \sim 77$ & $760-383$ \\
\hline 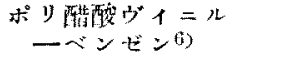 & $9.3 \sim 21.6$ & $4.52 \sim 283$ \\
\hline
\end{tabular}

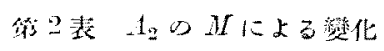

\section{3. 粘度との關係。}

疹透盟测分を共に，同じ試料に就いて Ostwald 型粘

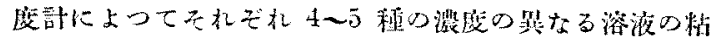

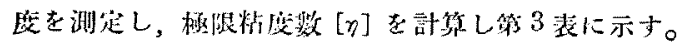

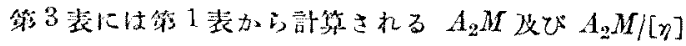
の值をのせて扎いた。

第3表に見ら礼る椂に $[\eta]$ 改び $A_{2} M$ は分子量 $M$ の

\begin{tabular}{|c|c|c|c|}
\hline 溶啠 & {$[\eta] \mathrm{cm}^{3} \mathrm{~g}^{-1}$} & $A^{3} M \mathrm{~cm}^{3} \mathrm{~g}^{-1}$ & $A^{2} M /[\eta]$ \\
\hline P. V.Ac. 21 & 18.9 & 14.8 & 1.28 \\
\hline P.V.Ac. $6 \mathbf{1}$ & 40.8 & 31.7 & 1.28 \\
\hline P.V.Ac. 202 & 48.0 & 29.0 & 1.65 \\
\hline P.V.Ac. 201 & 72.0 & 56.0 & 1.29 \\
\hline
\end{tabular}
㬗大と共に大きくなた。但し(2).武上り
第 3 表 P.V.Ac. $-\mathrm{MeOH}$ 采の $[\eta]$ と $A_{2} M$ との關保

$$
A_{2} M=A_{2} / A_{1}
$$

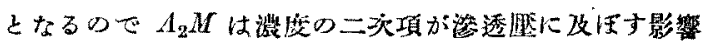
の度合を意味する。

第3 表に見られる样に少なく共本實驗では $A_{2} M /[\eta]$ 注 分子望によら才゙㱠んどー定值となつた。若しそらである なるば

$$
A_{2} M /[\eta]=K_{2}
$$

$K_{2}$ は次元的に無次元の最であり，これが一定となる ことは $A_{2}$ と粘成との间に根本的な關係がある事を喑示 する。

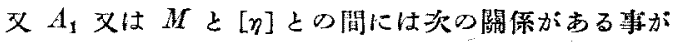
知放て居るて。

$$
[\eta]=K_{1} M^{a}
$$

從つて

$$
A_{2}=K_{1} K_{2} M^{-(1-\alpha)}
$$

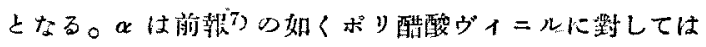
0.4〜0.8の䛧をとるので, $(1-\alpha)$ は正の値となるから，

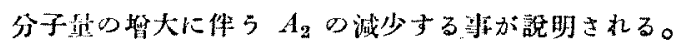

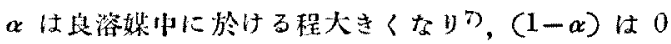
に近ずくのて，上記の閶保が一般に成立するものをすれ ば $A_{2}$ は $M$ の彎化によつて殆んど變化しなくなるを考

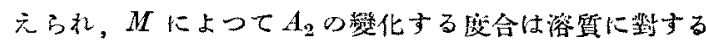

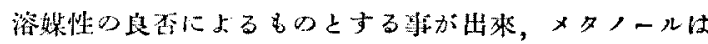

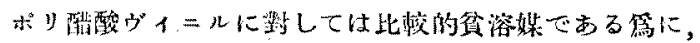
本测定に於いて性 $M$ の然大による $A_{2}$ の減少の度合加 比較的大きい梿となつたのであると考えられる。

P. J. Flory ${ }^{6)}$ は稀蒖溶液中に於ける高分子につき random coil model を用いて理論的計算を行つたが, その結果によ机ば，

$$
A_{2}=1.6[\eta] f / M=
$$

として表わされる。

ここに $f$ は 1 より小さい數で、本測定の場合には, 0.74〜0.82 と考元られる年。從つて， $\left.A_{2} M / \eta\right]$ は 1.18〜 1.31 となって本测定結果とよく一政する。

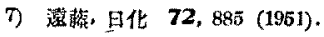

8) P, J. Flory, J. Chem. Phys. 13, 453 (1945). 
4. 總括

ポリ醋酸ヴィニルーメタノール系について濽透厎を测

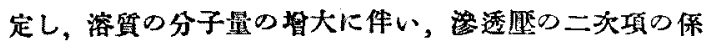

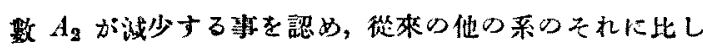

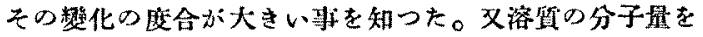

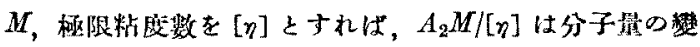
化にかかわらナ゙㱠んど一定であ石事を知つた。この關保 から $A_{2}$ と $M$ との關保を求め $A_{2} の M$ にる變化の 度合は溶媒性の良否に關保があると考えた。

(九州大學理學部化學敉室) (昭和 26 年 9 月 14 日受理)

\section{ニトロフェノール類の金屬錯監について（第 2 報 $)^{\prime \prime}$}

妻木 德一・天野 敏夫・中津誠一郎

前報に扎いてアンもニア及はアニりンを配位せる。一

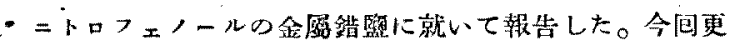
に數種のニトロフェノール類についてアンモニア及は種

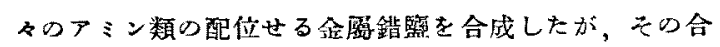
成㟵路にいくつかの型があることを見出したのでこれを 報告する。

前報に於いてジアンミン銅ーOーニトロフェノラート[B]

を合成した跱の称路は灭の如くであつた。

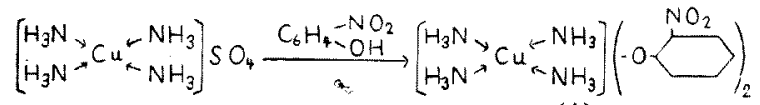

(A)

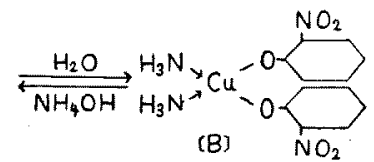

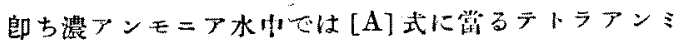
ン化合物として存在し、アンモニアが程ならすめられた 際に配位せる2分子のアンモニアは失われて[B]式をな つて目的の錯臨が得ら机る。更にらすいアンもニア液中

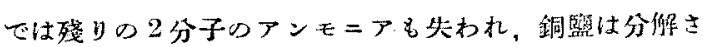
叔結局水酸化銅とのーニトロフェノールとになる。

然るに合可ジーp-トルイジノー䞒ーーートロフェノラー

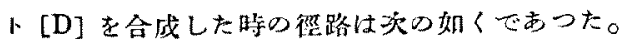
$\mathrm{Cu}\left(\mathrm{CH}_{3} \mathrm{COO}_{2} \stackrel{\mathrm{CH}_{3} \cdot \mathrm{C}_{6} \mathrm{H}_{4} \cdot \mathrm{NH}_{2}}{\longrightarrow}\left(\mathrm{CH}_{3} \cdot \mathrm{C}_{3} \mathrm{H}_{4} \cdot \mathrm{NH}_{2}\right)_{2} \cdot \mathrm{Cu}\left(\mathrm{CH}_{3} \mathrm{COO}_{2} \cdot 2 \mathrm{H}_{2} \mathrm{O}\right.\right.$ (C)

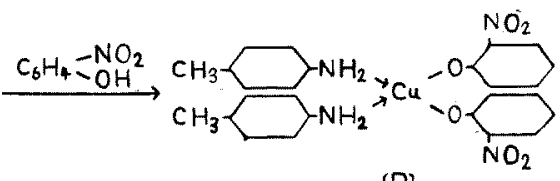

(D)

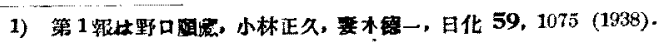

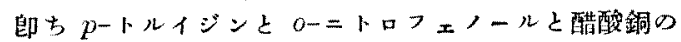

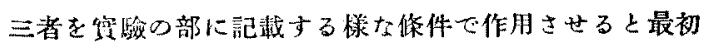
暗緣色の沈てんが生し，整時放置すると黑褐出の[D]に

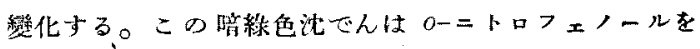

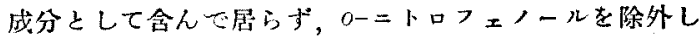

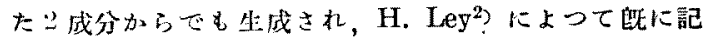

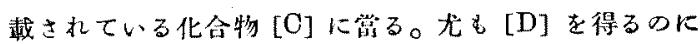
少しく保件を變えて, 醋酸銅の水溶液にのーニトロフェ ーール文び p-トルイジンのアルコール溶液を加え れば丩間體 [C] は得ら机ないで直接 [D]が得られ る。

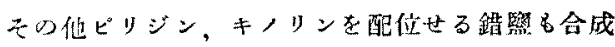
したが、これらは最初記したテトラアンミン゙型 [A] 心如き化合物怘得的机ない，又上記 [O] 型の中間 體も得ら机ないから直接ジピリジノ、ジキノリノ錯

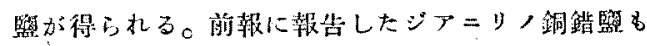
これと軦を一にする。

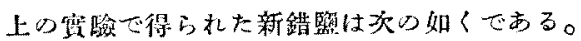

ジーp-トルィジノー銅ー0ーートロフェノラート

ジピリジノー銅ーO-ニトロフェノラート

ジキノリノー銅-Oーニトロフノラート

ジアンミンー銅-0・ートロー -

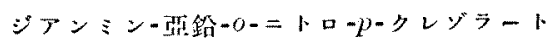

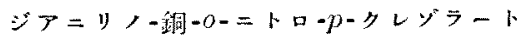

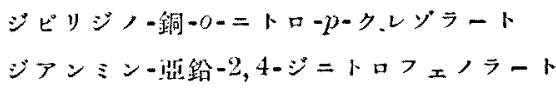

\section{菑 驗 の 部} ジーp-トルイジノ鍊ーo-ニトロフェノラート 2 $\mathrm{g}$ の

2) H. Ley, Ber, 42, 308 (1909). 